\title{
THE SCHOOL CLUB, THE SCHOOL GARDEN, AND CORRELATED SCHOOL ACTIVITIES
}

\author{
A. MONROE STOWE \\ State Normal School, Hyannis, Mass.
}

While at first thought there may seem to be little possible relation between the school club and the school garden, the former organized and conducted by the pupils of the upper elementary school to accomplish certain results which appeal to them as worthy of their efforts and which can be achieved only through co-operation, and the latter fast becoming a part of the curriculum, still the school club may be utilized by the school not only to make the work in gardening more interesting to the pupils, but also to assist in correlating with that work social and civic activities as well as school studies. It is the object of the present paper to indicate very briefly some of the ways in which the school club may be thus utilized.

The school club has just been defined as a club organized and conducted by the pupils of the upper elementary school to accomplish certain results which appeal to them as worthy of their efforts and which can be achieved only through co-operation. While this implies that the aims of the club must be very definite, yet if the club is to be an efficient agency for assisting the school in its endeavors to realize its educational ideals such as, for example, the vitalization of the curriculum, there must be tucked away somewhere in the constitution of the club an "elastic clause" which will permit it to undertake almost any form of work which may at any time interest the majority of its members. If there is such an "elastic clause" in the constitution of the school club, it should not be difficult to interest the members in the subject of gardening, since in most schools the pupils look forward with pleasure to their work in the garden. Indeed, in the majority of cases this interest will have to be molded rather than created, it will have to be socialized by developing it into a club or com- 
munity interest. This club interest may be awakened by proposing that the money made from a vegetable garden go into the club treasury to be expended by the club for some specified purpose, e. g., the purchase of books for the school- or villagelibrary. While to some this proposition may appear to savor of the "commercial," the "utilitarian," yet if accepted and worked out, it will offer many opportunities to introduce naturally and to present through vital experiences many school subjects as well as to teach many valuable lessons in the appreciation of the value of money.

If then our school club has become so interested in the subject of gardening that it has decided to organize all or a part of its members-the number depending upon the number who are to take the work-into a Committee on Gardening, entire charge of the garden may be given to this committee who should be impressed with their responsibility to make it as successful as possible from the financial point of view as well as from the standpoint of a model garden. While formerly there may have been little co-operation in the garden work due to the lack of a community feeling, there will now be more and more efficient co-operation as the community interests become stronger and stronger through their development in the organization and work of the Committee on Gardening.

As there is much important work to be done before work is begun in the garden, the organization of the Committee on Gardening ought not be delayed too long. Before proceeding with the election of the chairman and the secretary-treasurer, who is to keep the minutes of the committee and make regular reports to the club concerning what is being done, the committee should take time to discuss what qualifications make for a good officer, especially one to hold the office which it is about to fill. The result of such discussion will generally be the election of a pupil well qualified for the office. If this preliminary discussion takes place before all school-club elections, there will gradually be developed a habit of taking elections seriously, of weighing carefully the qualifications of the candidates, and of casting one's vote for the candidate considered best qualified, a habit 
which, if once formed and made permanent, will do much to reform political conditions in the near future. Thus even the work preliminary to gardening may be made to contribute toward the training of our pupils in and for citizenship.

After it has organized itself the Committee on Gardening may proceed to a discussion of what should be done befcre seedplanting time, the chair being occupied by the chairman and the teacher as adviser simply guiding the discussion. Much of this preliminary work, however, can be best taken up in class, leaving some of the following concrete, practical problems for discussion in committee :

I. From what vegetables shall we derive the most profit?

2. What method of caring for the garden shall we adopt? Shall we plant our vegetables in beds, each member having a plot, or shall we plant them in rows, each pupil being responsible for certain rows?

3. Which of these methods is favored by the kinds of vegetables we desire to raise? By the space we have at our disposal?

4. Which vegetables will grow best in this climate and in the soil of our garden?

After the Committee on Gardening has discussed the above problems, a special committee including the teacher might be chosen to draw up a plan for the garden, a task which will enable the pupils to utilize their knowledge of ratio and proportion in drawing the plan to a scale. When the report of the special committee has been approved, the Committee on Gardening with the help of seed catalogs obtained from seed firms will be able to figure upon the kind, amount, and cost of the seeds needed. While this committee is now ready to purchase its seed, it finds itself in the position of a man who desires to begin business but cannot do so until he obtains the necessary capital. What an excellent opportunity for introducing in a perfectly natural way the subject of borrowing money, promissory notes, interest, and even bank discount! How these subjects lose their abstract character when the committee is allowed by the teacher to borrow from some person connected with the school what money it needs for seeds and incidentals, giving a note signed by the secretarytreasurer for the committee and indorsed by the teacher as adviser! What a natural introduction to the subject of banks 
of deposit is offered when the secretary-treasurer deposits with the treasurer of the club the money borrowed and receives an account book and check book similar to those issued by banks of deposit except that "Treasury of School Club" is substituted for the name of a bank. If possible the other members of the Committee on Gardening should be furnished with duplicate books in order that they may keep duplicate records. There will be considerable practice in keeping accounts on the stubs as well as making out, indorsing, and presenting checks for payment, when checks are made out for money to be remitted with the various orders for seeds. In order to present through vital experience another phase of the subject the teacher may instruct the treasurer of the club how to keep the accounts of the Committee on Gardening and how to make monthly reports so that at the beginning of the following month the treasurer may give to the secretary-treasurer the canceled checks together with a statement similar to those rendered at the beginning of the month by banks of deposit.

The orders to which reference has just been made may be written by all of the pupils, the best copies being chosen to be sent to the seed firms and the secretary-treasurer being instructed to make checks payable to the pupils whose orders are to be sent. The necessity of sending remittances with these orders is a natural reason for introducing the subject of ways of making remittances through the mail, a subject which may be made more concrete to the pupils by allowing each to fill out properly an application for post-office money order in favor of one of the seed firms. When the proper applications have been filled out, a committee of three may be chosen to purchase the money orders and to report what takes place at the post-office. Following upon this report may come an account of what becomes of the duplicate orders as well as how the original orders are cashed, while the study of bills may be looked upon as following naturally upon the receipt of receipted bills for the seeds ordered.

While actual work in the garden, for which the pupils are now prepared, may go on much as in former years, the observant teacher will notice less of purely selfish individual effort and 
more of healthy and friendly co-operation, for the members of the Committee on Gardening are working out a plan to which all have given their approval and for the success of which all are earnestly striving moved by many motives, not the least important of which is the desire to have a model garden and to make their first financial undertaking a success. Thus by transforming individual effort into social co-operation as well as by offering wonderful opportunities for introducing naturally and presenting through vital experiences a number of important school studies, the school club through its Committee on Gardening may be of great assistance to the school in its endeavors to realize not only its purely educational ideal, the vitalization of its curriculum, but also its social ideal, the development of men and women trained to co-operate for the common good and welfare of their communities. 